\title{
Hypokalemic Rhabdomyolysis Induced Acute Renal Failure As a Presentation of Coeliac Disease
}

\author{
Funda Sarı, Ayşe Güneş, Metin Sarıkaya, Mustafa Eren, Ahmet Korkmaz, Ramazan Çetinkaya, Hasan Can, Nur Tukel \\ Clinic of Nephrology, Antalya Training and Research Hospital, Antalya, Turkey
}

\begin{abstract}
Adult coeliac disease commonly presents without classical symptoms as chronic diarrhea and weight loss. We describe the case of a 31 -year-old woman with persistent life-threatening hypokalemia, acute renal failure, and acute quadriplegia due to diarrhea that had continued for one month. Although there are cases of coeliac disease diagnosed with hypokalemic rhabdomyolysis in the literature, none of the cases developed acute renal failure. This is the first case in the literature diagnosed with acute renal failure due to hypokalemic rhabdomyolysis as a presentation of coeliac disease. In acute renal failure cases that present with hypokalemic rhabdomyolysis due to severe diarrhea, coeliac disease should be considered as a differential diagnosis despite the negative antigliadin IgA antibody.
\end{abstract}

Key Words: Adult coeliac disease, acute renal failure, hypokalemic rhabdomyolysis

Received: 02.06.2010

Accepted: 26.11 .2010

\section{Introduction}

When hypokalemia develops rapidly and becomes severe, muscle injury and rhabdomyolysis may occur (1). One of the causes of acute renal failure (ARF) is rhabdomyolysis. Many diseases causing hypokalemic rhabdomyolysis have been reported. Even though there are only a few cases, coeliac disease (CD) is a cause of hypokalemic rhabdomyolysis (2-7). This is the first case in the literature that presented with ARF due to hypokalemic rhabdomyolysis with regard to $C D$.

\section{Case Report}

A 31-year-old woman presented at the infection diseases department with diarrhea 10-15 times a day for one month, fatigue and weight loss. She had elevated serum blood urea nitrogen (BUN) and creatinine levels and severe hypokalemia. In the previous week, progressive muscle weakness had resulted in quadriplegia, severe generalized myalgia, and oliguria. Since the previous week, she had not been able to walk because of weakness. There was no history of any drug use. One week earlier, when she was admitted to the hospital, her physical examination was normal except for dehydratation and a fever of $38.2^{\circ} \mathrm{C}$. In the fecal examination, erythrocytes and leucocytes were seen; therefore, metronidazole $1000 \mathrm{mg}$ daily and ciprofloxacin $1000 \mathrm{mg}$ daily treatment was started. On admission, the patient's serum BUN, creatinine, sodium, potassium, hemoglobin, ferritin, parathormone and C-reactive protein levels were $30 \mathrm{mg} / \mathrm{dL}, 1.8 \mathrm{mg} / \mathrm{dL}, 131 \mathrm{mmol} / \mathrm{l}$, $1.8 \mathrm{mmol} / \mathrm{l}, 12 \mathrm{gr} / \mathrm{dL}, 48.3 \mathrm{ng} / \mathrm{mL}, 89 \mathrm{pg} / \mathrm{mL}$ and $13.1 \mathrm{mg} / \mathrm{mL}$, respectively. Blood, urine, and fecal cultures were negative, and serology for salmonella was negative. On the fourth day of treatment, she had no fever, but the treatment achieved no improvement in the diarrhea. There were no erythrocytes or leucocytes in fecal examination. Since BUN and creatinine levels increased and hypokalemia persisted despite adequate replacement, she was transferred to our nephrology clinic after one week of admission. Blood pressure was $100 / 60 \mathrm{mmHg}$, heart rate $96 \mathrm{bpm}$, breath sound 26/minute and body temperature was $37.2^{\circ} \mathrm{C}$. Generalized edema was present. There was a symmetrical and dominantly proximal muscular weakness of all extremities. Bilateral respiratory sounds could not be heard. Laboratory findings were shown in Table 1. Sedimentation rate and CRP were normal. Arterial blood gas showed metabolic acidosis ( $\mathrm{PH}$ :7.28 PCO2:37 HCO3:18). Urine output, proteinuria and creatinine clearance were detected as $400 \mathrm{cc} /$ day, $2.1 \mathrm{gr} /$ day and $11.5 \mathrm{ml} /$ $\mathrm{min} / 1.73 \mathrm{~m}^{2}$, respectively. The spot urine sample showed potassium $9 \mathrm{mmol} / \mathrm{l}$, sodium $31 \mathrm{mmol} / \mathrm{l}$, and $\mathrm{pH}$ lower than 5 with normal sediment. On fecal examination, no erythrocytes, leucocytes, Entamoeba histolytica trophozoites or cysts, and Giardia cysts were detected. The fecal culture was negative. Serologic tests for HIV and hepatitis $B$ and $C$ viruses were negative. TSH, cortisol, and ferritin levels were normal. P/A chest $\mathrm{X}$-ray showed bilateral pleural effusion. Abdominal ultrasound examination revealed that the bilateral renal sizes and parenchymal echogenicities were normal with no pelvicalyceal dilatation. On the EKG, a $U$ wave and a prolonged QT interval were detected. IgA antigliadin antibody was negative. Colonoscopy was normal. Gastroscopy revealed normal 
Table 1. Changes in blood laboratory tests

\begin{tabular}{|c|c|c|c|c|c|}
\hline & $\begin{array}{l}\text { On admission } \\
\text { infectious disease clinic }\end{array}$ & $\begin{array}{l}\text { On admission } \\
\text { nephrology clinic }\end{array}$ & $\begin{array}{l}\text { After one week } \\
\text { on admission } \\
\text { nephrology clinic }\end{array}$ & $\begin{array}{l}\text { After two weeks } \\
\text { on admission } \\
\text { nephrology clinic }\end{array}$ & $\begin{array}{c}\text { After seven } \\
\text { weeks on admission } \\
\text { nephrology clinic }\end{array}$ \\
\hline BUN (mg/dL) & 30 & 27 & 41 & 23 & 19 \\
\hline Creatinine $(\mathrm{mg} / \mathrm{dL})$ & 1.8 & 3.7 & 4.5 & 2.5 & 0.9 \\
\hline $\mathrm{Na}(\mathrm{mg} / \mathrm{dL})$ & 131 & 132 & 131 & 136 & 138 \\
\hline $\mathrm{K}(\mathrm{mmol} / \mathrm{l})$ & 1.8 & 1.2 & 1.8 & 4.9 & 5 \\
\hline $\mathrm{Ca}(\mathrm{mg} / \mathrm{dL})$ & 6.2 & 6.6 & 6.6 & 7.7 & 8.9 \\
\hline$P(m g / d L)$ & 2 & 1.7 & 1.7 & 5 & \\
\hline Albumin (g/dL) & 3.6 & 3.6 & 3.8 & 3.7 & \\
\hline $\mathrm{CK}(\mathrm{ng} / \mathrm{mL})$ & & 55000 & 10000 & 488 & 147 \\
\hline AST (U/l) & 750 & 850 & 640 & 52 & 44 \\
\hline $\mathrm{LDH}(\mathrm{U} / \mathrm{l})$ & 1100 & 1250 & 793 & 500 & 274 \\
\hline \multicolumn{2}{|c|}{ Spot urine K (mmol/l) } & 9 & & & \\
\hline \multicolumn{2}{|c|}{ Spot urine $\mathrm{Na}(\mathrm{mmol} / \mathrm{l})$} & 31 & & & \\
\hline \multicolumn{2}{|l|}{$\mathrm{Ph}$} & 7.28 & & & \\
\hline \multicolumn{2}{|l|}{$\mathrm{HCO}_{3}$} & 18 & & & \\
\hline \multicolumn{2}{|l|}{$\mathrm{PCO}_{2}$} & 37 & & & \\
\hline
\end{tabular}

gastric mucosa and duodenal mucosa, from which biopsies were taken. Duodenal biopsy revealed subtotal atrophy, flattening and loss of villi.

Hydration and replacement of electrolytes were started. Since the patient's urine output was inadequate and BUN and creatinine levels progressively elevated, hemodialysis was considered. After daily hemodialysis therapy, $\mathrm{K}$ levels increased to normal ranges, muscle weakness improved, and adequate urine output was achieved. A gluten-free diet was started and diarrhea was ameliorated.

\section{Discussion}

The first finding of celiac disease is mostly iron deficiency anemia among adults with CD (7). In our case, the patient did not exhibit iron deficiency anemia on admission. Due to the identifying etiology of diarrhea, the fecal examination for parasitosis, fecal cultures, serology for salmonella, viral hepatitis, and HIV were negative. Colonoscopy was normal. IgA antigliadin antibody was negative. It is known that IgA antigliadin antibody measurement with ELISA has $75 \%-87 \%$ sensitivity in adults with $C D(6,8)$. Thus, we performed a gastroscopic biopsy of the duodenum and diagnosed celiac disease.

We diagnosed ARF due to rhabdomyolysis because of the elevated serum muscle enzyme levels. We considered that the etiology of rhabdomyolysis was hypokalemia due to the patient's prolonged severe diarrhea. Injury of the cells causes the efflux of cellular components such as myoglobin and creatine kinase into the circulation, and then rhabdomyolysis occurs. Myoglobin in the renal glomerular filtrate may precipitate, leading to renal obstruction and renal damage. Furthermore, myoglobin is an inhibitor of nitric-oxide bioactivity and causes intrarenal vasoconstriction and ischemia.
It has been established that rhabdomyolysis is not an uncommon cause of $A R F$, with an incidence rate of $5 \%-25 \%$ $(9,10)$. ARF develops in $10 \%-50 \%$ of patients with rhabdomyolysis (11). It is admitted that, for ARF to occur in cases of hypokalemic rhabdomyolysis, a number of conditions such as dehydration, acidosis, physical exercise, or nephrotoxic drugs should also be present (10). In our patient, ARF rapidly developed, probably due to rhabdomyolysis accompanying acidosis and dehydration caused by severe diarrhea. The reported causes of hypokalemic rhabdomyolysis include renal tubular acidosis, Bartter syndrome, diuretics, laxative, Conn's syndrome, etc $(12,13)$. The first case of hypokalemic rhabdomyolysis caused by CD was reported in 1982; since then, six additional cases have been reported in which CD started with rhabdomyolysis induced by hypokalemia (2-5). This is the first case in the literature that presented with ARF due to hypokalemic rhabdomyolysis with regard to $C D$.

We started potassium replacement with intensive intravenous hydration; but since it may cause a reduction in plasma potassium concentration secondary to intracellular shift, we did not consider the alkalinization. Hypocalcaemia occurs in the first few days because of the deposition of calcium salts in damaged muscle and decreased bone responsiveness to parathyroid hormone $(14,15)$. Because of this probability, we avoided calcium replacement.

To prevent ARF due to rhabdomyolysis, there is no specific treatment except to maintain fluid and electrolyte balance and preserve tissue perfusion. Once volume overload, hyperkalemia, acidemia, and uremia develop, dialysis should be initiated. During the follow-up period, our patient required dialysis. After daily dialysis therapy for one week, her muscle enzymes levels decreased, and her serum electrolyte imbalance improved. Due to the gluten-free diet, the diarrhea was ameliorated. 
In summary, in ARF cases that present with hypokalemic rhabdomyolysis due to severe diarrhea, CD should be considered as a differential diagnosis. Despite negative antigliadin antibodies, endoscopic biopsy should be performed to diagnose CD.

\section{Conflict of Interest}

No conflict of interest was declared by the authors.

\section{References}

1. Larner AJ. Potassium depletion and rhabdomyolysis. BMJ 1994;308:136. [CrossRef]

2. Williams SG, Davison AG, Glynn MJ. Hypokalaemic rhabdomyolysis: an unusual presentation of coeliac disease. Eur J Gastroenterol Hepatol 1995;7:183-4.

3. Selimoglu MA, Alp H, Ertekin V. Is rhabdomyolysis a rare manifestation in celiac disease? Yonsei Med J 2004;45:759-60.

4. Barta Z, Miltenyi Z, Toth L, Illes A. Hypokalemic myopathy in a patient with gluten-sensitive enteropathy and dermatitis herpetiformis Duhring: a case report. World J Gastroenterol. 2005;11: 2039-40.

5. Peña Porta JM, Calvo Beguería E, de Vera Floristán CV, Oncins Torres R. Hypokalemic rhabdomyolysis and tetany as a presentation of celiac disease in an adult. Nefrología 2008;28:343-6.

6. Casellas i Jordà F. Celiac disease. Med Clin (Barc) 2006;126: 137-42.
7. Jones S, D'Souza C, Haboubi NY. Patterns of clinical presentation of adult coeliac disease in a rural setting. Nutr J 2006,5:24. [CrossRef]

8. Ankelo M, Kleimola V, Simell S, Simell O, Knip M, Jokisalo E, et al. Antibody responses to deamidated gliadin peptide show high specificity and parallel antibodies to tissue transglutaminase in developing coeliac disease. Clin Exp Immunol 2007;150:285-93. [CrossRef]

9. Singhal PC, Abramovici M, Venkatesan J, Mattana J. Hypokalemia and rhabdomyolysis. Miner Electrolyte Metab 1991;17: 335-9.

10. Ward M. Factors predictive of acute renal failure in rhabdomyolysis. Arch Intern Med 1988;148:1553-7. [CrossRef]

11. Grossman R, Hamilton R, Morse B, Penn A, Goldberg M. Nontraumatic rhabdomyolysis and acute renal failure. $\mathrm{N}$ Engl J Med 1974;291:807-11. [CrossRef]

12. Menahem SA, Perry GJ, Dowling J, Thomson NM. Hypokalaemia-induced acute renal failure. Nephrol Dial Transplant 1999;14:2216-8. [CrossRef]

13. Kishore B, Thurlow V, Kessel B. Hypokalaemic rhabdomyolysis. Ann Clin Biochem 2007;44:308-11. [CrossRef]

14. Llach F, Felsenfeld AJ, Haussler MR. The pathophysiology of altered calcium metabolism in rhabdomyolysis-induced acute renal failure. Interactions of parathyroid hormone, 25-hydroxycholecalciferol, and 1,25-dihydroxycholecalciferol N Engl J Med 1981;305:117-23. [CrossRef]

15. Akmal M, Bishop JE, Telfer N, Norman AW, Massry SG. Hypocalcemia and hypercalcemia in patients with rhabdomyolysis with and without acute renal failure. J Clin Endocrinol Metab 1986;63:137-42 [CrossRef] 